\title{
Media coverage of climate change: an international comparison
}

Article

Accepted Version

Barkemeyer, R., Figge, F., Hoepner, A., Holt, D., Kraak, J. M. and $\mathrm{Yu}, \mathrm{P}$. S. (2017) Media coverage of climate change: an international comparison. Environment and Planning C:

Politics and Space, 35 (6). pp. 1029-1054. ISSN 2399-6544 doi: https://doi.org/10.1177/0263774X16680818 Available at https://centaur.reading.ac.uk/73358/

It is advisable to refer to the publisher's version if you intend to cite from the work. See Guidance on citing.

Published version at: http://dx.doi.org/10.1177/0263774X16680818

To link to this article DOI: http://dx.doi.org/10.1177/0263774X16680818

Publisher: SAGE

All outputs in CentAUR are protected by Intellectual Property Rights law, including copyright law. Copyright and IPR is retained by the creators or other copyright holders. Terms and conditions for use of this material are defined in the End User Agreement.

\section{www.reading.ac.uk/centaur}

\section{CentAUR}

Central Archive at the University of Reading 
Reading's research outputs online 


\section{Media coverage of climate change: An international comparison}

\section{Ralf Barkemeyer}

Kedge Business School (Bordeaux), France

\section{Frank Figge}

Kedge Business School (Marseille), France
Environment and Planning C: Government and Policy 0 (0) $1-25$

(C) The Author(s) 2016 Reprints and permissions: sagepub.co.uk/journalsPermissions.nav DOI: $10.1177 / 0263774 \times 16680818$ epc.sagepub.com

@SAGE

\author{
Andreas Hoepner \\ University of Reading, UK; Stockholm School of Economics, Sweden
}

\title{
Diane Holt
}

University of Essex, UK

\section{Johannes Kraak}

INSEEC Business School (Bordeaux), France

\section{Pei-Shan Yu}

University of Reading, UK; Stockholm School of Economics, Sweden

\begin{abstract}
We present an international comparison of broadsheet newspaper coverage of climate change. We employ two complementary theoretical lenses, multiple streams theory and institutional theory, to explore why climate change has become headline news in some countries but has received comparatively little coverage in others. The study utilises a worldwide sample across 4 I different countries for the year 2008, covering II3 leading national broadsheet newspapers. A cross-sectional regression model is used to identify whether and how a range of contextual factors impact coverage of climate change. To a certain extent, a country's direct exposure to climate change and the measures that have been taken to combat global warming influence the position of climate change on the media agenda. Crucially, however, we identify a number of contextual factors that impact climate change-related media coverage in different national contexts. In particular, we find a significantly positive relationship between regulatory quality and levels of media coverage. At the same time, unemployment trends are significantly negatively related to media attention to climate change. Gross domestic product per capita does not help to explain levels of climate change-related media coverage. In other words, climate change appears to have moved beyond simply being a 'rich country issue'.
\end{abstract}

\section{Corresponding author:}

Ralf Barkemeyer, Kedge Business School (Bordeaux), 680 Cours de la Libération, 33405 Talence cedex, France.

Email: ralf.barkemeyer@kedgebs.com 


\section{Keywords \\ Climate change, institutional theory, media coverage, multiple streams theory, agenda setting, broadsheet newspapers}

\section{Introduction}

Coinciding with increasing scientific and political attention, the issue of climate change and its potential risks to humankind, have clearly permeated into the mass media agenda (Moser, 2010). Extreme weather events such as Hurricane Katrina in 2005, Typhoon Haiyan in 2013, or the frequent number of heat waves have triggered increased levels of climate change-related media coverage. In addition, technical events such as the releases of Intergovernmental Panel on Climate Change (IPCC) reports in 2007 and 2013/14 as well as the United Nations Climate Change Conferences (COPs) have become international media events (Boykoff, 2010; Holt and Barkemeyer, 2012). Yet, at best effective policy approaches are still only emerging with public awareness and support varying widely across countries and regions. Notwithstanding the increasingly complex media landscape and the emergence of social media, broadsheet newspapers continue to play a crucial role as agenda setters and as mirrors of public concern in relation to climate change (Carvalho and Burgess, 2005; Ungar, 2000). As such, cross-national research exploring the mechanisms that impact media attention will be key to better understanding why climate change has firmly entered the media agenda in some contexts but less so in others (Anderson, 2009; Boykoff and Roberts, 2007; Moser, 2010).

Consequently, this paper aims to shed light on factors that drive media attention to climate change across a sample of 113 leading broadsheet newspapers from 41 countries, focusing on the year 2008. We employ two complementary theoretical lenses in order to shed light on contextual factors that influence the media agenda. Whilst multiple streams theory (Kingdon, 1984) allows us to capture the impact of a number of factors directly related to climate change, institutional theory helps us to explore wider contextual factors that could plausibly explain national-level variation in media attention to climate change.

A cross-sectional regression model is used to identify whether these factors, as well as newspaper characteristics, serve to explain levels of climate change-related media coverage in the 41 countries in our sample. We find that a multitude of contextual factors shape media coverage of climate change. Crucially, neither a country's exposure to climate change nor its track record in relation to climate policy appears to be the main determinants of media attention to climate change. Instead, a number of wider contextual factors are at least as relevant in shaping the media agenda. First and foremost, effective national-level governance - measured as regulatory quality - is significantly positively related to levels of media coverage on climate change. Likewise, unemployment trends also play a part in shaping the media agenda. At the same time, we find that climate change has moved beyond simply being a 'rich country issue', as levels of gross domestic product (GDP) do not help to explain levels of climate change-related media coverage.

We contribute to the existing literature in two ways. First, our approach helps to gain a more thorough understanding of why climate change has entered the media agenda in some countries but has largely failed to do so in others. More specifically, we widen the perspective from factors that are directly linked to climate change and climate policy (Liu et al., 2011; Schäfer et al., 2014; Schmidt et al., 2013), and shed light on the wider contextual factors that shape the media agenda. Second, we move beyond the hitherto strong focus on developed country contexts in the analysis of climate change and the mass media (Anderson, 2009; Boykoff and Roberts, 2007; Schäfer and Schlichting, 2014). Whilst numerous 
(typically country-specific) developing and emerging economy perspectives on the topic have been published in recent years (Gordon et al., 2010; Takahashi and Meisner, 2013), we utilise a comprehensive sample of both developed and developing country publications in order to enable a more systematic comparison, to shed light on general factors that drive or inhibit climate change-related media coverage across nations.

The remainder of this paper is structured as follows: In the next section, we review the role of the mass media in agenda setting along with the two theoretical lenses employed in this study, multiple streams theory and institutional theory. As part of this section, we develop a number of hypotheses regarding the relationship of a number of contextual factors and media attention to climate change. We then describe the data and analysis methods used in our study. Subsequently, results of the analysis are presented and discussed in light of global climate policy. Before concluding, we discuss policy implications with regard to the observed cross-country differences in levels of media attention to climate change, including driving factors and how these could be utilised to build support for a transition towards low carbon economies.

\section{Theory development}

\section{Climate change and the media agenda}

Communication is a key factor in the context of climate change (Pidgeon, 2012). A range of authors have stressed the role of the mass media in informing and mobilising the general public as well as reflecting public opinion (Anderson, 2009; Boykoff and Boykoff, 2007). Within the agenda-setting literature, it has long been acknowledged that the media 'may not be successful much of the time in telling people what to think, but [they are] stunningly successful in telling its readers what to think about' (Cohen, 1963: 13). As such, increased media attention to a certain issue typically indicates increased public attention and, in turn, increased likelihood that the political system takes up the issue (Leiserowitz, 2005).

Generally, print publications are assumed to have a stronger agenda-setting impact than, for example, television news (Boykoff, 2010; McCombs, 1977). Among these, broadsheet or 'quality' newspapers such as the Guardian or the Times have long been argued to stand out as they typically provide a higher amount of coverage on political issues and also have a higher agenda-setting impact for policy makers and the general public than, for instance, tabloid newspapers (Carvalho and Burgess, 2005; McCombs, 2004). In addition, it has been argued that broadsheet newspapers serve as 'inter-media agenda setters', i.e. they in turn shape the agendas of other media such as television news and tabloid coverage (McCombs, 2004). In recent years, the emergence of social media and the relative decline of traditional newspapers may have altered the agenda-setting function of broadsheet newspapers; nevertheless, they arguably continue to be relevant agenda setters.

For the purposes of this study as well as related research, broadsheet newspapers also have the advantage that their content can easily be accessed through depositories such as LexisNexis or Factiva. As such, measuring media attention by the volume, or frequency, of broadsheet newspaper coverage has long been a common method in agenda-setting research (Howlett, 1997; Kiousis, 2004). Examples in the context of climate change include countrylevel analyses of quality newspapers in the US (Boykoff, 2007; Boykoff and Boykoff, 2007; McComas and Shanahan, 1999), the UK (Boykoff and Mansfield, 2008; Carvalho and Burgess, 2005) and various continental European countries (Aykut et al., 2012; Kleinschmit and Sjöstedt, 2014; Pasquaré and Oppizzi, 2012). More recently, a number of studies have also started to explore media coverage in emerging and developing economies such as Mexico (Gordon et al., 2010), Peru (Takahashi and Meisner, 2013), Bangladesh 
(Miah et al., 2011), China (Yang, 2010) or India (Jogesh, 2012). In addition, a limited number of international comparative analyses of climate change-related media coverage exist, including Brossard et al. (2004), Grundmann and Scott (2014), Holt and Barkemeyer (2012), Nerlich et al. (2012), Schäfer et al. (2014) or Schmidt et al. (2013).

Two general patterns emerge from these various studies: (a) in recent years, a substantial increase in coverage of climate change could be identified in most if not all countries under review, typically peaking in 2007 (Nobel Peace Prize awarded to Al Gore and the IPCC) and/ or 2009 (COP15 in Copenhagen). At the same time, (b) clear country-level differences can be observed with regard to actual levels of coverage (Boykoff and Roberts, 2007; Schäfer et al., 2014; Schmidt et al., 2013). Whilst climate change has become headline news in some countries, media attention has remained comparatively marginal in others. Consequently, in this article we employ an international sample of broadsheet newspapers in order to address the following research question:

Research Question: Which factors drive media attention to climate change?

We choose two complementary and well-established theoretical lenses, multiple streams theory (Kingdon, 1984) and institutional theory (Jepperson, 1991; Powell and DiMaggio, 1991), to approach this research question.

\section{Multiple streams theory}

Multiple streams theory provides us with an established and testable analytical framework that has also been used in prior enquiries into climate change and agenda setting (Liu et al., 2011; Schäfer et al., 2014). According to multiple streams theory, there are three central dimensions - or 'streams' - that will determine the levels of media attention devoted to a specific issue: the problem stream, the policy stream and the political stream (Kingdon, 1984).

The problem stream focuses on the actual condition of particular issues. Crucially, in addition to considering specific condition indicators it also recognises that these indicators reflect a real problem: 'conditions become problems when we feel we should do something to change them' (Kingdon, 1993: 42). [AQ2] A poignant example in the context of climate change is the Keeling curve, which maps out concentrations of carbon dioxide in the atmosphere. Whilst these measurements go back to the year 1959 (Keeling et al., 1995), only recently has significant general consensus emerged that the Keeling curve describes a global environmental problem that does indeed require urgent action.

The policy stream refers to the existence of competing policy ideas on a given issue that are seen as feasible and acceptable to the general public. A plethora of different ideas and policy proposals have emerged aimed at adapting to and mitigating the effects of climate change, both at the international level as well as at the level of individual nation states. Finally, the political stream focuses on oftentimes sudden shifts in the political landscape such as elections, specific campaigns or events that have the potential to impact public perception on a given issue.

In the context of climate change, previous studies have operationalised these three streams as 'problem indicators', 'focusing events' and 'feedback' (Liu et al., 2011; Schäfer et al., 2014). Here, problem indicators describe the magnitude of the problem underlying a specific issue, focusing events trigger increased levels of public attention to the issue at stake and feedback takes the form of communications of societal groups in response to problem indicators or focusing events. Each of these streams can impact 
climate change-related media attention. However, following Kingdon (1984), only when all three streams work in combination, is any given issue likely to occupy a leading position on the media agenda.

In line with multiple streams theory, we would therefore expect problem indicators to influence the extent to which climate change enters the media agenda in different countries. Whilst climate change can be seen as a global environmental problem, its specific impacts may nevertheless vary considerably in different country contexts. For example, it is likely to be perceived as more immediately threatening from the perspective of Small Island Developing States than from the perspective of most continental European States. The occurrence of a series of events that are perceived as imminent personal threats to the general public can be expected to elevate a particular problem onto the media agenda in a given context (Ungar, 2000). Some argue that increased occurrences of severe weather events has driven public awareness and has in turn led to higher media attention to climate change (Boykoff and Roberts, 2007; Demeritt, 2001; however, see Poumadère et al. (2005) for a contrasting view). Along these lines, increased levels of media coverage and public awareness have been attributed to large-scale droughts in the US (Boykoff and Boykoff, 2007; Boykoff and Roberts, 2007; Demeritt, 2001) or a series of cyclones in Australia (Henderson-Sellers, 1998). Bord et al. (2000) find evidence for this link at the level of individual perceptions in a US setting. Schäfer et al.'s (2014) analysis of Australian, German and Indian broadsheets provides evidence for the impact of severe weather events on media attention to climate change in the German context but not for the other two countries. Adopting the dominant view across these studies, we would expect a positive link between climate change-related risk and media attention to climate change for the countries included in our sample.

\section{Hypothesis 1a. The extent to which a country is exposed to risks associated with climate change is} positively related to levels of media attention to climate change.

We apply a simple aggregated measure to capture country-level risk associated with climate change. The Germanwatch 'Global Climate Risk Index 2010' (Harmeling, 2010) quantifies the negative impact of weather-related loss events on GDP between 1990 and 2008, and provides average rankings for all countries included in our sample. Risk index scores range between 25.83 (India) and Singapore (161.92), where lower values represent higher exposure risk to negative impacts of climate change.

Previous research has operationalised the policy stream and the political stream of multiple streams theory as focusing events and feedback (Liu et al., 2011; Schäfer et al., 2014). Whilst the most significant focusing events such as the COPs or the launch of the IPCC reports arguably occurred in the international arena (rather than the level of individual nation states), there is nevertheless clear variation in these national-level policy efforts directed at climate change, which may in turn affect media attention to climate change. In line with this assumption, Schäfer et al. (2014) find that national-level feedback processes are significantly positively related to levels of media attention climate change receives in Australia, Germany and India. The same link is confirmed by Liu et al. (2011) in a US setting. For the purposes of this study, we focus on the actual outcomes of national-level policy processes. It is reasonable to assume that higher levels of feedback and, more generally, policy activity will result in more effective national-level policies in relation to climate change. In turn, these can be expected to positively influence media attention to this issue. We therefore hypothesise:

Hypothesis 1b. Country-level policy effectiveness directed at climate change is positively related to levels of media attention to climate change in these countries. 
In order to quantify policy effectiveness directed at climate change, we turn to the Germanwatch 'Climate Change Performance Index 2008' (Burck et al., 2008) which evaluates a country's efforts to mitigate the impacts of global climate change. Climate Change Performance Index scores for the year 2008 for the countries included in our sample range from 38.9 (Canada) to 65.3 (Germany).

At the same time, it is important to note that in previous international comparative analyses, these climate change-related factors only provided partial explanations for the identified country-level variations in media attention (Schäfer et al., 2014; Schmidt et al., 2013). It is reasonable to assume that beyond the three elements of multiple streams theory, a number of other contextual factors may help to explain why climate change occupies different positions on the media agenda in different countries. In order to shed light on these contextual factors, we complement multiple streams theory with an institutional theory perspective, as operationalised by the National Business Systems (NBS) approach (Ioannou and Serafeim, 2012; Whitley, 1999).

\section{Institutional theory}

Institutional theory views institutions both as formal and informal rules and as embedded cultural norms, ideologies and beliefs (Jepperson, 1991; Powell and DiMaggio, 1991). A central tenet of institutional theory is that organisations and actors by and large behave rationally, but that their rationality is bounded by the amount of information they have at their disposal and the way in which this information is interpreted (Tolbert and Zucker, 1999). To a certain extent, national-level institutions thus shape individual-level decision making. This assumption is an implicit element of Kingdon's (1984) multiple streams theory where the widespread recognition that a problem indicator actually constitutes a problem is needed for increased media attention to occur.

Within the institutional literature, the NBS perspective has explored how national-level institutions shape how organisations and even entire economic systems are organised (Ioannou and Serafeim, 2012; Whitley, 1999; Witt and Redding, 2013). Whitley (1999: 33) defines NBSs as 'distinctive patterns of economic organization that vary in their degree and mode of authoritative coordination of economic activities, and in the organization, and interconnections between owners, managers, experts, and other employees'. Four dimensions constitute an NBS: (1) the political system, (2) the financial system, (3) the labour system and (4) the cultural system (Matten and Moon, 2008).

According to Whitley (1999), the political system refers to the nature and effectiveness of governance processes, encompassing aspects such as industrial policy, collective bargaining or the regulation of markets. A country's financial system is characterised by aspects such as availability, allocation and pricing of capital. The labour system refers to 'the institutions that control the terms on which the owners of those skills sell them in labour markets and how those markets are organized' (Whitley, 1999: 50). Finally, the cultural system refers to 'the development of collective identities and prevalent modes of eliciting compliance and commitment within authority systems' (Whitley, 1999: 51) and has been found to shape the nature of NBS. Together, these four subsystems/dimensions shape economic systems as well as organisations and individuals that are embedded within them.

The NBS approach has been used in a number of international comparative analyses and helped to develop testable propositions regarding the impact of nation-level institutional factors on corporate governance (Aguilera and Jackson, 2003), innovation systems (Lundvall, 1999), human resource management (Ferner and Quintanilla, 1998) and more 
recently on cross-national differences in corporate social responsibility practices (Ioannou and Serafeim, 2012; Jackson and Apostolakou, 2010; Matten and Moon, 2008).

For the purposes of this research, we loosely follow the NBS perspective to structure our enquiry into national-level institutions that may shape media attention to climate change. In essence, we argue that beyond the climate change-specific factors that are covered by our application of multiple streams theory, news media are furthermore embedded in a range of national-level institutions that in turn also influence levels of media attention to a specific issue such as climate change. Following the general structure of the NBS framework, we distinguish between four types of contextual (i.e. political, economic, labour related and cultural) factors that are likely to influence the position of climate change on the media agenda.

Political dimension. In line with previous research (Liu et al., 2011; Schäfer et al., 2014) and as captured by Hypothesis 1b, we would expect a country's efforts in the domain of climate policy to be positively related to media attention to climate change; seeing a direct relationship between a country's policy efforts and media attention. Beyond this direct relationship, however, it is also reasonable to assume that a link exists between media attention and the quality and effectiveness of a country's governance processes more generally.

Arguably a 'global policy convergence' can be identified, creating similar policy solutions in different nation states (Tews et al., 2003; Weidner and Jänicke, 2002). However, convergence mostly refers to the formal policy regime that is created. Thus, a distinction needs to be made between substantial and symbolic institutionalisation, with the latter being merely symbolic measures that lack sufficient resources and enforcement powers to have a substantial impact (Weidner and Jänicke, 2002). The existence of independent media that play an effective role in a country's agenda-setting processes may also contribute to effectively addressing various policy issues. In the domain of environmental protection, functioning environmental institutions have long been seen as indicative for high levels of environmental awareness (Longhofer and Schofer, 2010). In turn, a country's track record of successfully formulating and implementing sound policies can be expected to increase the likelihood of new policy issues entering the media and public agenda.

We hypothesise:

Hypothesis 2. The quality of a country's regulatory regime is positively related to levels of media coverage of climate change.

We use an aggregated indicator provided by the World Bank (2014) called 'regulatory quality' to measure the quality of a country's regulatory regime. Here, regulatory quality 'captures perceptions of the ability of the government to formulate and implement sound policies and regulations that permit and promote private sector development' (World Bank, 2014). For the countries included in our sample, regulatory quality scores range between -1.37 (Venezuela) and 1.97 (Hong Kong).

Economic dimension. One basic way of describing a national economy is in terms of its level of economic development, which is generally expected to be positively related to the level of certain environmental problems. Typically, increasing affluence results in higher consumption of environmental resources. However, at the same time levels of economic development can be expected to be positively related to the emergence of technological solutions to a number of environmental problems (Grossman and Krueger, 1991), such as 
standardised, affordable end-of-pipe technologies (Weidner and Jänicke, 2002). The environmental Kuznets curve (Galeotti et al., 2006; Stern et al., 1996) builds on this assumption of a decoupling of economic growth and environmental impacts.

In the context of climate change, it has been well documented that a positive relationship exists between levels of economic development and levels of carbon emissions (UNDP, 1995). This link, based on the carbon-intensive consumption patterns evident in all Western societies, would also seem to imply that higher levels of awareness will be awarded to this issue in countries with higher levels of economic development. In addition, for environmental problems that are not perceived as immediately life threatening it has long been argued that when levels of income are low or insecure, more emphasis will be put on the satisfaction of basic needs rather than the quality of the environment (Inglehart and Baker, 2000; Maslow, 1943). Whilst the interrelations between poverty and climate change have been widely acknowledged (Forsyth, 2007; UNDP, 2007), problems linked to low levels of economic development can to a certain extent be expected to crowd out less immediate concerns such as climate change (Kolk and Pinkse, 2011; Michaelowa and Michaelowa, 2007). We therefore hypothesise

Hypothesis 3a. A country's level of economic development is positively related to levels of media coverage of climate change.

As the indicator for a country's level of economic development, we follow standard convention and employ GDP per capita for the year preceding the newspaper coverage (Guiso et al., 2006). GDP per capita data are taken from the Global Market Information Database.

Likewise, it could be expected that in countries with a higher carbon intensity, climate change is perceived as a more pressing challenge. Along these lines, Schmidt et al. (2013) find that climate change receives particularly high levels of media coverage in carbon dependent countries. We therefore hypothesise

Hypothesis 3b. A country's carbon intensity is positively related to levels of media coverage of climate change.

As the indicator for a country's carbon intensity, we employ the amount of country-level $\mathrm{CO}_{2}$ emissions $(\mathrm{kg})$ per GDP (PPP, 2005) for the year preceding the newspaper coverage, with data taken from the International Energy Agency (IEA, 2016). [AQ3]

Another relevant feature of a country's financial system is the extent to which it is integrated into the world economy. Countries with a high degree of international trade might have a more international outlook and be more attentive to challenges that are discussed in the international arena, whereas relatively closed economies can be expected to be less concerned with global environmental problems such as climate change.

Hypothesis $3 c$. The extent to which a country is integrated into the world economy is positively related to levels of media coverage of climate change.

The ability to attract foreign direct investment (FDI) is one significant dimension of a country's integration into the world economy. We therefore measure the extent to which a country is integrated into the world economy as FDI intensity, i.e. the amount of FDI inflows as a percentage of a country's GDP. FDI intensity data are again taken from the Global Market Information Database.

Labour dimension. Supply and demand of labour can be expected to have implications that go far beyond a country's labour market. High levels of unemployment have the potential to 
shift a country's economic policy into the spotlight of public attention, and to crowd out other concerns such as climate change, in particular given the long-term nature and high levels of scientific uncertainty that surround climate change. It has repeatedly been argued that the extent of climate change coverage in the mass media is affected by the occurrence of competing events such as an economic downturn (Anderson, 2009). In a US setting, unemployment levels have repeatedly been found to be significantly negatively related to levels of public concern for climate change (Brulle et al., 2012; Kahn and Kotchen, 2010). We therefore expect that this crowding-out effect will also impact levels of media attention to climate change.

Hypothesis 4. Country-specific unemployment trends are negatively related to levels of media attention to climate change.

We use a country's unemployment rate as a percentage of its economically active population for the year 2008 compared to the decadal average for the years 1998-2007. Unemployment data are taken from the Global Market Information Database and ranges between $-5.94 \%$ (Venezuela) and $+1.84 \%$ (India).

Cultural dimension. Finally, we can also expect country-specific cultural norms and values to influence the way in which climate change is framed and the extent to which it is perceived as an urgent and important challenge. Due to its elusive nature, culture is notoriously difficult to operationalise (Taras et al., 2009). This can be illustrated by the fact that even the most widespread and well-established instruments such as those developed by Hofstede (1980), Trompenaars and Hampden-Turner (1997) or the GLOBE survey (House et al., 2004) continue to be at the centre of controversial debates questioning the validity of any such instruments (see e.g. Hofstede, 2006; Taras et al., 2009).

For this reason, we turn to religious beliefs as one specific element of culture that is easier to operationalise. The link between religious denominations and environmentalism has received widespread attention, for example in the form of 'deep core beliefs' (Sabatier and Jenkins-Smith, 1999) or 'world views' (Stedman, 2004; Stern et al., 1995). In a US context, Eckberg and Blocker (1996) find support for White's thesis that Christian beliefs have an anti-environmental effect (White, 1967). Dietz et al. (1998) more generally identify differences between different religious denominations in terms of attitudes towards the environment. However, these studies have not produced consistent results: 'Neither membership in any given religious denomination nor the intensity of religious participation seem to be linked to environmental concern' (Franzen and Meyer, 2010: 220). Typically, significant differences between denominations, beliefs or practices have been attributed to fundamentalist views within a given society rather than reflecting more general views held by the public (Dietz et al., 1998).

Extant research has typically focused on a single country, with the USA (and the 1993 General Social Survey) as a dominant area of enquiry (Eckberg and Blocker, 1996; Guth et al., 1995). One of the few exceptions is the cross-country perspective adopted by Schultz et al. (2000), who identify commonalities in the religion-environmentalism relationship across a range of North American and Latin American countries. Since they focus on respondents holding Judeo-Christian beliefs, this type of pattern may therefore not exist where Christianity is not the dominant religious denomination. Furthermore, differences may exist within different denominations subsumed as Judeo-Christian, e.g. between countries holding predominantly Catholic or Protestant views. Adopting this perspective to country-level variation of media attention to climate change, we expect different religious denominations to influence the dominant framing of climate change and thus 
lead to differences in the perceived urgency and importance of this challenge, thus resulting in differences in levels of media attention to climate change.

Hypothesis 5. The distribution of religious denominations in a specific country is related to levels of media attention to climate change.

For this hypothesis, we utilise the percentage of the population in a country that adheres to a certain religious denomination as our measure. The CIA World Factbook (2012) provides information on the distribution of religious denominations within the countries included in our sample.

Table 1 summarises the organising framework we apply in combination with the set of independent variables that have been introduced above.

\section{Data and methods}

\section{Data sample}

Our study contributes to identifying contextual factors that drive climate change-related media coverage at international levels. We employ a sample covering the full-text content of approximately 2,600,000 articles in 32,000 newspaper issues across 113 newspapers based in 41 different countries for the year 2008. The criteria for newspaper selection included circulation, area of circulation and, if possible, private ownership. Newspapers were selected that were not predominantly local or regional in scope and therefore, at least to a certain extent, reflected their national public agendas. Priority was given to national broadsheet papers as these can be expected to provide the highest amount of coverage on political issues and to have the highest agenda-setting impact for policy makers and the general public (Carvalho and Burgess, 2005; Sparks, 1987). Selection was restricted to a maximum of eight per country (e.g. USA, UK, Germany) to limit geographical bias and arrive at a varied selection.

The sample of newspapers from non-OECD countries was more limited; for example, it was not possible to include any African newspapers beyond South Africa. In some cases, such as Russia, Japan, China (Hong Kong) or South Africa, the analysis was restricted to national newspapers that are published in the English language, although data were included for papers published in the eight specified other languages. ${ }^{1}$ Where possible, the political alignment of newspapers was considered to ensure a minimum level of representativeness and to arrive at a reasonably balanced sample.

In 2007, the release of the IPCC report and the award of the Nobel Peace Prize to Al Gore and the IPCC (Barkemeyer et al., 2009; Holt and Barkemeyer, 2012) elevated climate change to the status of a global media event. In many countries, media attention to climate change peaked in around this time, followed by a decline in subsequent years (Schmidt et al., 2013). Therefore, the year 2008 was chosen as the specified time frame after these trigger events and because media coverage throughout 2008 remained relatively stable and not biased towards single events as it was in 2007 or $2009 / 10$ (i.e. media coverage linked to the Copenhagen Summit in 2009/2010). This is also reflected by the fact that average standard deviations of monthly coverage for the 113 newspapers included in the sample are clearly lower in 2008 $(S D=10.1)$ than in $2007(S D=16.1)$ and $2009(S D=19.6)$, respectively. Nevertheless, equivalent datasets were also collected for the years 2007 and 2009 and the analysis was replicated for all three years as a robustness check in which results were qualitatively equivalent.

Data were collected using keyword searches of the LexisNexis and Factiva newspaper databases. The technique used can be described as text/data mining (Hearst, 1997, 1999; 
Table I. Organising framework (adapted from Kingdon (1984) and Whitley (1999)).

\begin{tabular}{|c|c|c|c|c|}
\hline Source & Dimension & $\begin{array}{l}\text { Aspect explored within } \\
\text { this dimension }\end{array}$ & Independent variable & Hypothesis \\
\hline \multirow[t]{2}{*}{ Multiple streams theory } & Problem stream & $\begin{array}{l}\text { Country-level exposure to } \\
\text { climate change-related risks }\end{array}$ & $\begin{array}{l}\text { Germanwatch 'Global Climate Risk } \\
\text { Index 20I0' score (Harmeling, } \\
2010 \text { ) }\end{array}$ & la \\
\hline & Policy stream & $\begin{array}{l}\text { Country-level policy efforts } \\
\text { directed at climate change }\end{array}$ & $\begin{array}{l}\text { Germanwatch 'Climate Change } \\
\text { Performance Index 2008' (Burck } \\
\text { et al., 2008) }\end{array}$ & $\mathrm{lb}$ \\
\hline \multirow[t]{6}{*}{$\begin{array}{l}\text { National business systems } \\
\text { perspective }\end{array}$} & Political dimension & $\begin{array}{l}\text { Quality of a country's regulatory } \\
\text { regime }\end{array}$ & $\begin{array}{l}\text { World Bank (2014) Governance } \\
\text { Indicators; 'Regulatory Quality' } \\
\text { dimension }\end{array}$ & 2 \\
\hline & Economic dimension & $\begin{array}{l}\text { Level of a country's economic } \\
\text { development }\end{array}$ & $\begin{array}{l}\text { GDP per capita for the year } \\
\text { preceding period under review } \\
\text { (Global Market Information } \\
\text { Database, 20I5) [AQ14] }\end{array}$ & $3 a$ \\
\hline & & $\begin{array}{l}\text { Level of a country's carbon } \\
\text { dependency }\end{array}$ & $\begin{array}{l}\text { Carbon intensity }\left(\mathrm{kg} \mathrm{CO}_{2} / \mathrm{GDP} \text { per }\right. \\
\text { capita) for the year preceding } \\
\text { period under review (IEA, 20I6) }\end{array}$ & $3 b$ \\
\hline & & $\begin{array}{l}\text { A country's integration into the } \\
\text { world economy }\end{array}$ & $\begin{array}{l}\text { FDI intensity (FDI as a percentage of } \\
\text { GDP) (Global Market } \\
\text { Information Database, 20I5) } \\
\text { [AQ15] }\end{array}$ & $3 c$ \\
\hline & Labour dimension & Unemployment rate & $\begin{array}{l}\text { Unemployment rate (\% of } \\
\text { economically active population) } \\
\text { for the year preceding period } \\
\text { under review compared to } \\
\text { decadal average (Global Market } \\
\text { Information Database) }\end{array}$ & 4 \\
\hline & Cultural dimension & Religious denominations & $\begin{array}{l}\text { Distributions of religious } \\
\text { denominations in a given country } \\
\text { (CIA World Factbook, 20I2) }\end{array}$ & 5 \\
\hline
\end{tabular}


Table 2. Newspaper sample [AQ16].

\begin{tabular}{|c|c|c|}
\hline $\mathrm{Nb}$ & Country & Publication Name \\
\hline I & AR & La Nación \\
\hline 2 & AT & Die Presse \\
\hline 3 & AT & Wirtschaftsblatt \\
\hline 4 & $\mathrm{AU}$ & Daily Telegraph \\
\hline 5 & $\mathrm{AU}$ & Herald Sun \& Sunday Herald Sun \\
\hline 6 & $A U$ & The Age \\
\hline 7 & $\mathrm{AU}$ & The Australian \\
\hline 8 & $\mathrm{AU}$ & The Canberra Times \\
\hline 9 & $\mathrm{AU}$ & The Courier Mail \\
\hline 10 & $\mathrm{AU}$ & The Sydney Morning Herald \\
\hline 11 & $\mathrm{BE}$ & De Tijd \\
\hline 12 & $\mathrm{BR}$ & O Globo \\
\hline 13 & $\mathrm{CA}$ & National Post \\
\hline 14 & CA & The Globe and Mail \\
\hline 15 & CA & The Toronto Star \\
\hline 16 & $\mathrm{CA}$ & The Vancouver Sun \\
\hline 17 & CA & Toronto Sun \\
\hline 18 & $\mathrm{CH}$ & La Tribune de Genève \\
\hline 19 & $\mathrm{CH}$ & Le Matin \\
\hline 20 & $\mathrm{CH}$ & Le Temps \\
\hline 21 & $\mathrm{CH}$ & Tages-Anzeiger \\
\hline 22 & $\mathrm{CL}$ & El Mercurio \\
\hline 23 & $\mathrm{CN}$ & South China Morning Post \\
\hline 24 & $\mathrm{CO}$ & Portafolio \\
\hline 25 & $C R$ & Al Día \\
\hline 26 & $C R$ & La Nación \\
\hline 27 & $C Z$ & The Prague Post \\
\hline 28 & $\mathrm{DE}$ & Berliner Zeitung \\
\hline 29 & $\mathrm{DE}$ & die tageszeitung \\
\hline 30 & $\mathrm{DE}$ & Die Welt \\
\hline 31 & $\mathrm{DE}$ & Frankfurter Rundschau \\
\hline 32 & $\mathrm{DE}$ & Hamburger Abendblatt \\
\hline 33 & $\mathrm{DE}$ & Stuttgarter Zeitung \\
\hline 34 & $\mathrm{DK}$ & Borsen \\
\hline 35 & $\mathrm{DK}$ & Politiken \\
\hline 36 & EC & El Comercio \\
\hline 37 & ES & $A B C$ \\
\hline 38 & ES & Diario Montañés \\
\hline 39 & ES & Diario Vasco \\
\hline 40 & ES & El Correo \\
\hline 41 & ES & El Mundo \\
\hline 42 & ES & El Pais \\
\hline 43 & ES & La Verdad \\
\hline 44 & $\mathrm{FR}$ & La Tribune \\
\hline 45 & $\mathrm{FR}$ & Le Figaro \\
\hline 46 & FR & Le Monde \\
\hline 47 & FR & Le Parisien \\
\hline 48 & $\mathrm{FR}$ & L'Humanité \\
\hline 49 & FR & Libération \\
\hline
\end{tabular}


Table 2. Continued.

\begin{tabular}{|c|c|c|}
\hline $\mathrm{Nb}$ & Country & Publication Name \\
\hline 50 & FR & Ouest-France \\
\hline 51 & $\mathrm{FR}$ & Sud Ouest \\
\hline 52 & GT & Siglo Veintiuno \\
\hline 53 & IE & Irish Examiner \\
\hline 54 & IE & Irish Independent \\
\hline 55 & IE & The Irish Times \\
\hline 56 & $\mathrm{IL}$ & The Jerusalem Post \\
\hline 57 & IN & Hindustan Times \\
\hline 58 & IN & MINT \\
\hline 59 & $\mathrm{IT}$ & La Stampa \\
\hline 60 & $J P$ & Mainichi Daily \\
\hline 61 & $J P$ & The Daily Yomiuri (Tokyo) \\
\hline 62 & $\mathrm{JP}$ & The Japan Times \\
\hline 63 & KG & The Times of Central Asia \\
\hline 64 & $\mathrm{KR}$ & Korea Herald \\
\hline 65 & $\mathrm{KR}$ & Korea Times \\
\hline 66 & $M X$ & El Universal \\
\hline 67 & MX & Reforma \\
\hline 68 & MY & New Straits Times \\
\hline 69 & NL & AD/Haagsche Courant \\
\hline 70 & NL & Dagblad De Limburger \\
\hline 71 & $\mathrm{NL}$ & De Telegraaf \\
\hline 72 & NL & De Volkskrant \\
\hline 73 & NL & Het Financieele Dagblad \\
\hline 74 & $\mathrm{NL}$ & NRC Handelsblad \\
\hline 75 & NL & Trouw \\
\hline 76 & NP & Nepali Times \\
\hline 77 & NZ & The Dominion Post \\
\hline 78 & NZ & The New Zealand Herald \\
\hline 79 & NZ & The Press (Christchurch) \\
\hline 80 & PE & El Comercio \\
\hline 81 & $\mathrm{PH}$ & Manila Times \\
\hline 82 & PK & The Nation \\
\hline 83 & $\mathrm{RU}$ & The Moscow Times \\
\hline 84 & SG & The Business Times \\
\hline 85 & SG & The Straits Times \\
\hline 86 & $\mathrm{TH}$ & The Nation \\
\hline 87 & UK & Belfast Telegraph \\
\hline 88 & UK & Daily Telegraph \\
\hline 89 & UK & Financial Times \\
\hline 90 & UK & Guardian \\
\hline 91 & UK & Independent \\
\hline 92 & UK (/IE) & Irish News \\
\hline 93 & UK & The Herald \\
\hline 94 & UK & The Observer \\
\hline 95 & UK & Times \\
\hline 96 & US & El Nuevo Dia (Puerto Rico) \\
\hline 97 & US & Los Angeles Times \\
\hline 98 & US & New York Times \\
\hline
\end{tabular}


Table 2. Continued.

\begin{tabular}{lll}
\hline $\mathrm{Nb}$ & Country & Publication Name \\
\hline 99 & US & The Boston Globe \\
100 & US & The Daily News \\
101 & US & The Philadelphia Inquirer \\
102 & US & USA Today \\
103 & US & Washington Post \\
104 & UY & El País \\
105 & VE & El Nacional \\
106 & ZA & Business Day \\
107 & ZA & Cape Argus \\
108 & ZA & Cape Times \\
109 & ZA & Daily News \\
110 & ZA & Financial Mail \\
111 & ZA & Pretoria News \\
112 & ZA & The Mercury \\
113 & ZA & The Star \\
\hline
\end{tabular}

Manning and Schütze, 2002). Text mining generates patterns or knowledge from unstructured or semi-structured text (Feldman and Sanger, 2007; Tan, 1999). For each issue, stemming algorithms were developed that allowed for the inclusion of possible variations in spelling, conjunction or misspelling of key terms, developed for the eight different languages included (English, French, German, Spanish, Portuguese, Dutch, Danish and Italian). Binary document frequencies (df) were calculated to transform the data. Essentially, all articles that contained at least one mention of the respective search term in the full text body were included.

Table 3 provides an overview of average coverage levels of climate change in terms of the average number of articles per newspaper issue for the countries included in the sample (see also Appendix 1 for a graphical representation). Australian newspapers received the highest coverage levels across the sample with an average of 3.9 articles per newspaper issue. In other words, on average every one of the seven Australian newspapers included in the sample contained almost four articles that referred to climate change in each newspaper issue throughout the year 2008. At the other end of the spectrum, less than one article could be found in every 10 newspaper issues in Venezuela (0.09), Guatemala (0.08), Ecuador (0.07), Costa Rica (0.07) and Russia (0.04). Across the sample, every newspaper issue in 2008 contained 1.20 articles on climate change.

\section{Econometric analysis}

We develop our econometric model based on Puglisi and Snyder's (2011) one-stage analysis. Puglisi and Snyder analyse the newspaper coverage of political scandals using coverage per article as dependent variable which satisfies OLS requirements in their study. We use coverage per issue as a dependent variable instead of coverage per article. In other words, we identify the average absolute number of climate change-related articles per newspaper, but control for newspaper length. This allows us to separate questions of editorial decision making with regard to newspaper content from a size effect linked to the length of newspapers. However, we use articles per issue as a control variable and our dependent variable coverage per issue has statistically very similar properties to Puglisi and Snyder's 
Table 3. Average number of climate change-related articles per newspaper issue and standard deviation of monthly coverage levels per country.

\begin{tabular}{|c|c|c|c|c|}
\hline $\mathrm{Nb}$ & Country & $\begin{array}{l}\mathrm{Nb} \text { of } \\
\text { Newspapers }\end{array}$ & M (2008) & $\begin{array}{l}\text { SD (monthly } \\
\text { averages, 2008) }\end{array}$ \\
\hline I & Argentina & I & 0.15 & 0.11 \\
\hline 2 & Australia & 7 & 3.90 & 2.10 \\
\hline 3 & Austria & 2 & 0.59 & 0.41 \\
\hline 4 & Belgium & I & 0.46 & 0.22 \\
\hline 5 & Brazil & I & 0.10 & 0.05 \\
\hline 6 & Canada & 5 & 2.24 & 1.00 \\
\hline 7 & Chile & I & 0.25 & 0.11 \\
\hline 8 & China & I & 1.01 & 0.38 \\
\hline 9 & Colombia & I & 0.24 & 0.16 \\
\hline 10 & Costa Rica & 2 & 0.07 & 0.08 \\
\hline 11 & Czech Republic & I & 0.18 & 0.20 \\
\hline 12 & Denmark & 2 & 0.20 & 0.14 \\
\hline 13 & Ecuador & I & 0.07 & 0.05 \\
\hline 14 & France & 8 & 0.33 & 0.21 \\
\hline 15 & Germany & 6 & 1.58 & 0.49 \\
\hline 16 & Guatemala & I & 0.08 & 0.04 \\
\hline 17 & India & 2 & 1.97 & 1.84 \\
\hline 18 & Ireland (Rep.) & 4 & 1.30 & 1.09 \\
\hline 19 & Israel & I & 0.25 & 0.22 \\
\hline 20 & Italy & I & 0.41 & 0.21 \\
\hline 21 & Japan & 3 & 0.23 & 0.29 \\
\hline 22 & Kyrgyzstan & I & 0.10 & 0.11 \\
\hline 23 & Malaysia & I & 0.54 & 0.21 \\
\hline 24 & Mexico & 2 & 1.26 & 1.13 \\
\hline 25 & Nepal & I & 0.31 & 0.29 \\
\hline 26 & Netherlands & 7 & 0.72 & 0.43 \\
\hline 27 & New Zealand & 3 & 1.23 & 0.72 \\
\hline 28 & Pakistan & I & 0.16 & 0.06 \\
\hline 29 & Peru & I & 0.35 & 0.24 \\
\hline 30 & Philippines & I & 0.20 & 0.18 \\
\hline 31 & Russia & I & 0.04 & 0.04 \\
\hline 32 & Singapore & 2 & 0.69 & 0.28 \\
\hline 33 & South Africa & 8 & 0.58 & 0.44 \\
\hline 34 & South Korea & 2 & 0.54 & 0.22 \\
\hline 35 & Spain & 7 & 2.19 & 1.28 \\
\hline 36 & Switzerland & 4 & 0.19 & 0.21 \\
\hline 37 & Thailand & I & 0.54 & 0.35 \\
\hline 38 & UK & 8 & 3.00 & 2.07 \\
\hline 39 & Uruguay & I & 0.18 & 0.07 \\
\hline 40 & USA & 8 & 0.89 & 0.64 \\
\hline 41 & Venezuela & I & 0.09 & 0.06 \\
\hline \multicolumn{2}{|c|}{ Total sample (I-4I) } & 113 & 1.20 & 1.43 \\
\hline
\end{tabular}


dependent variable coverage per article. In fact, after we take the natural logarithm of our dependent variable, its distribution appears normal according to a Jarque-Bera test ( $\mathrm{p}$-value 0.41 ) and shows no sign of any positive skewness. Hence, we are confident in estimating cross-sectional OLS regressions with White heteroskedasticity consistent covariance matrices. We specify our key independent variables introduced in the hypotheses developed in the preceding section in two further ways. In the case of religious denominations, we limit our attention in testing hypothesis 5 to five major world religions: Buddhism, Christianity, Hinduism, Islam and Judaism.

Beside our key independent variables, we employ two newspaper-specific control variables and two sets of fixed effects. Our first newspaper-specific control variable is articles per issue estimated based on the following procedure. For each newspaper included in the sample, subsamples were drawn covering one week of total coverage. Based on the average number of total articles per week and the number of newspaper issues per week, the average number of articles published per newspaper issue was calculated. We introduce this control variable, as the sheer size of a newspaper can obviously affect its quantity of coverage per issue.

Our second newspaper-specific variable is a dummy variable which was coded as 1 if a newspaper had a local focus, and coded 0 otherwise. Coding was based on newspaperspecific information collected from the newspaper databases LexisNexis and Factiva as well as the European Journalism Centre (EJC, 2015). We introduce this control variable based on the assumption that newspapers focusing on a more locally interested readership will under-proportionally cover the global topic of climate change. We introduce regional fixed effects to control for unobserved and unobservable regional variation in media coverage. Our language fixed effects control for unobserved and unobservable languagerelated cultural effects and a potential language bias in the dependent variable.

\section{Discussion of results}

The results are displayed in Table 4. Specifications one and two simply display the strength of our control model as a benchmark before adding the key independent variables in the final specification. Our control model, with only newspaper specific factors, results in expected and statistically highly significant coefficients (positive in case of articles per issue, negative in case of local focus) and an adjusted R-squared of 47\%. In comparison, Puglisi and Snyder's (2011) one-stage analysis yielded, at best, an adjusted R-squared of $8 \%$. This difference confirms our view that coverage per issue as dependent variable with articles per issue as control is the more informative research design compared to coverage per article as dependent variable, since it distinguishes the managerial discretion of coverage per issue from the strategic decision of articles per issue. When adding regional fixed effects to our control model, the adjusted R-squared remains at $47 \%$, which is a reasonable explanatory power for a cross-sectional model.

Specifications 3-7 in Table 4 display our individual hypotheses tests. As can be seen, three out of our five individual hypotheses are at least supported when tested individually. Specifications 8-9 in Table 4 display our joint hypotheses tests. Here, significant relationships can only be identified for hypotheses 2 and 4 . With regard to hypothesis 1a, Climate Risk Index scores are found to have significantly positive impacts on media attention to climate change in the single hypothesis test. However, it should be noted that the effect size is very modest and the effect becomes insignificant once hypotheses are tested jointly. No significant impact is found throughout for Climate Change performance scores (hypothesis 1b). Therefore, hypotheses $1 \mathrm{a}$ and $1 \mathrm{~b}$ need to be rejected. Regulatory quality is clearly positively related to the media attention to climate change in our sample, providing 
Table 4. Regression results.

\begin{tabular}{|c|c|c|c|c|c|c|c|c|c|}
\hline Specification number: & (I) & $(2)$ & (3) & $(4)$ & (5) & $(6)$ & (7) & $(8)$ & (9) \\
\hline Specification title: & $\begin{array}{l}\text { Control } \\
\text { model }\end{array}$ & $\begin{array}{l}\text { (I) With } \\
\text { regional } \\
\text { fixed effects }\end{array}$ & $\begin{array}{l}\text { Test of } \\
\text { hypothesis I }\end{array}$ & $\begin{array}{l}\text { Test of } \\
\text { hypothesis } 2\end{array}$ & $\begin{array}{l}\text { Test of } \\
\text { hypothesis } 3\end{array}$ & $\begin{array}{l}\text { Test of } \\
\text { hypothesis } 4\end{array}$ & $\begin{array}{l}\text { Test of } \\
\text { hypothesis } 5\end{array}$ & $\begin{array}{l}\text { Joined test } \\
\text { of six } \\
\text { hypotheses }\end{array}$ & $\begin{array}{l}\text { With language } \\
\text { fixed effects }\end{array}$ \\
\hline \multicolumn{10}{|l|}{ Hypothesis I: } \\
\hline Climate risk index & & & $0.01 *$ & & & & & -0.01 & -0.01 \\
\hline Climate change performance & & & 0.01 & & & & & 0.01 & 0.02 \\
\hline \multicolumn{10}{|l|}{ Hypothesis 2: } \\
\hline Regulatory quality & & & & $0.54^{* * * *}$ & & & & $1.08^{* * * *}$ & $0.78^{* *}$ \\
\hline \multicolumn{10}{|l|}{ Hypothesis 3: } \\
\hline GDP per capita & & & & & 0.00 & & & $-0.00 *$ & -0.00 \\
\hline Carbon intensity & & & & & 0.78 & & & 0.06 & -1.61 \\
\hline FDI intensity & & & & & 0.03 & & & 0.05 & 0.07 \\
\hline \multicolumn{10}{|l|}{ Hypothesis 4: } \\
\hline Unemployment (deviation) & & & & & & 0.05 & & -0.11 & $-0.18^{*}$ \\
\hline \multicolumn{10}{|l|}{ Hypothesis 5: } \\
\hline$\%$ of Buddhists & & & & & & & -0.66 & -0.51 & -0.46 \\
\hline$\%$ of Christians & & & & & & & -0.81 & -0.45 & 0.13 \\
\hline$\%$ of Hindus & & & & & & & -0.41 & 0.64 & 0.38 \\
\hline$\%$ of Jews & & & & & & & $-1.34^{*}$ & $-0.32 *$ & -0.22 \\
\hline$\%$ of Muslims & & & & & & & $-0.27^{*}$ & -0.28 & 0.03 \\
\hline None & & & & & & & 0.34 & -0.55 & 0.96 \\
\hline \multicolumn{10}{|l|}{ Newspaper characteristics: } \\
\hline Articles per issue & $1.04^{* * * *}$ & $1.17^{* * * * *}$ & $1.12^{\text {**** }}$ & $0.99 * * *$ & 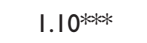 & $1.18^{* * * *}$ & $1.20^{* * * *}$ & 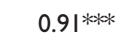 & $0.81^{* * *}$ \\
\hline Local focus & -0.39 & -0.28 & -0.20 & -0.08 & -0.18 & -0.21 & -0.21 & -0.22 & -0.24 \\
\hline \multicolumn{10}{|l|}{ Fixed effect controls : } \\
\hline Regional fixed effects & No & Yes & Yes & Yes & Yes & Yes & Yes & Yes & Yes \\
\hline Language fixed effects & No & No & No & No & No & No & No & No & Yes \\
\hline Observations: & 113 & 113 & 113 & 113 & 113 & 113 & 113 & 113 & 113 \\
\hline Adjusted R-squared: & 0.47 & 0.47 & 0.48 & 0.54 & 0.49 & 0.47 & 0.48 & 0.54 & 0.62 \\
\hline
\end{tabular}

FDI: foreign direct investment; GDP: gross domestic product.

Explanation: This table displays the regression results of our Puglisi and Snyder (20II) one-stage analysis. The dependent variable is the natural logarithm of the average climate change coverage per issue in II 3 newspapers in 2008. In its logged form, the hypothesis of a normal distribution of the dependent variable cannot be rejected (Jarque-Bera $\mathrm{P}$-value of $0.4 \mathrm{I}$ ). Independent variables are displayed in the rows and explained in further detail in the main text. The first two specifications display the control model. Specifications $3-7$ test hypotheses I-5 individually. The eighth specification represents a joint test of all hypotheses and the ninth specification informs the possibility of language bias in this joint hypotheses test. The underlying covariance matrices are White heteroskedasticity consistent. The base region for the regional fixed effects is Europe. *, ** and $* * *$ represent a 5 , I and $0.1 \%$ significance level, respectively. 
clear support for hypothesis 2 . The result is strongly statistically significant and supports the view that it is not only the existence of functioning environmental institutions (Longhofer and Schofer, 2010), but also a functioning policy regime more generally that is an important precondition for increased media attention to climate change.

With regard to hypothesis $3 \mathrm{a}$, levels of economic development do not appear to drive levels of climate change-related media coverage. Hypothesis $3 a$ therefore needs to be rejected. This is contrary to our expectation and insights from previous research (Inglehart and Baker, 2000; Kolk and Pinkse, 2011). However, in unreported results without regional dummies, GDP per capita is positively significant. In other words, GDP per capita as a variable leads broadly in the right direction; however, there are other factors which are more directly related to climate change coverage. ${ }^{2}$ Along similar lines, hypotheses $3 \mathrm{~b}$ (carbon intensity) and $3 \mathrm{c}$ (integration into the world economy) need to be rejected. Thus, neither a country's carbon dependency nor its integration into the world economy appears to have a significant impact on levels of media attention to climate change.

No significant effect can be identified for levels of unemployment when hypothesis 4 is tested individually. However, a significantly negative effect can be identified once language fixed effects are included in the joint hypothesis tests. Hypothesis 4 is therefore supported. This result confirms the view that the extent to which climate change receives coverage in the mass media is crowded out by competing concerns (Anderson, 2009), in this case concern for unemployment. Finally, with regard to hypothesis 5, the distribution of religious denominations within a specific country shows small but partially significant effects on levels of media attention. When hypothesis 5 is tested individually, a significantly negative relationship is only identified in the case of Jewish and Muslim denominations at a 5\% confidence level. For Jewish denominations, this relationship also emerges as significantly negative when hypotheses are tested jointly; however, it does not remain significant once language fixed effects are included, leading us to reject hypothesis 5. When splitting Christian religions into Catholic and Protestant denominations, unreported specifications show that there are also no consistent significant effects for either religious denomination.

It is noteworthy that the above findings are robust to regional fixed effects and language fixed effects. Moreover, the adjusted R-squared only shows a moderate increase of $8 \%$ when language fixed effects are introduced, which shows that potential language bias is limited in our joint hypothesis test.

When interpreting the results above, it should be kept in mind that all newspapers under review showed relatively high coverage on climate change compared to previous years with the exception of 2007 as the year immediately preceding the period under review. Yet the results described earlier provide insights into factors that have led to increased or decreased levels of media attention to climate change across a sample comprising broadsheet newspapers from 41 countries. The results show that whilst - in line with previous research (Schäfer et al., 2014; Schmidt et al., 2013) - country-level efforts to address climate change can provide partial explanations for country-level variation in media attention to climate change, the wider context also plays an important role in shaping the media agenda. As such, institutional theory has provided us with a useful analytical lens to complement Kingdon's (1984) multiple streams theory and to explore the wider context in which the media agenda is constructed.

Furthermore, the results document that climate change has emerged as a truly global problem that is not merely confined to affluent or well-educated regions of the global North. However, whilst levels of economic development do not have a significant impact, the wider governance context emerges as a key factor for media attention to climate change. Effective governance might in fact provide the enabling environment in which not only climate policy 
is seen as a viable avenue to pursue, but also in which the media can more effectively inform and mobilise the general public and reflect public opinion (Boykoff and Boykoff, 2007) in relation to climate change.

From a policy-making perspective, important implications emerge from the absence of a significant relationship between a country's exposure to climate change-related risk and levels of climate change-related media coverage. At first sight, this finding appears counterintuitive, as a number of severe weather events (such as US droughts and cyclones in Australia as discussed earlier) are linked to increased media attention to climate change.

However, our findings appear to confirm previous studies which argue that the general public may demonstrate a cognitive dissonance; failing to make the link between negative weather events and the complex and long-term challenge of climate change (Lorenzoni et al., 2007; Poumadère et al., 2005; Ungar, 2000; to a certain extent also Schäfer et al., 2014). At present, short-term, highly visible negative weather events appear to have the immediacy that turns them newsworthy, while climate change - even if related - may instead be perceived as something more distant in time and space. Educating the media as well as the general public about potential links between these remains a pivotal challenge for policy-makers. This is further highlighted by the crowding-out effect that has been observed in relation to levels of unemployment.

\section{Conclusion}

In this paper, we have analysed levels of media attention to climate change as measured by relative levels of broadsheet newspaper coverage on the topic. Our contribution to the extant literature is to provide a better understanding of the determinants of climate change-related media attention across a diverse cross-country sample. If one can agree that there needs to be widespread public support for measures that effectively address climate change (Milfont, 2012), then levels of media attention arguably serve as a precondition for any type of widespread support. The extensive sample allows us to identify general patterns across a set of 113 broadsheet newspapers from 41 countries and thus to go beyond case study-based research as well as quantitative studies based on specific national or regional contexts, thereby also addressing the hitherto existing bias towards the OECD region in this body of literature.

Throughout our sample relatively high levels of media attention to climate change could be observed in 2008, triggered by global events at the time. However, our results show that a number of contextual factors have a significant (positive or negative) impact on relative levels of media coverage in the countries under review. Crucially, factors that drive media coverage are not restricted to a country's exposure to climate change or its mitigation efforts. Instead, the wider context in which climate policy and media production occur plays a significant role in this context, and in particular effective governance.

The current findings provide a sound base for further cross-national research into the determinants of climate change-related media attention. As discussed, an area of future research that is immediately linked to this study is an in-depth analysis of the impact of economic development on media attention to climate change. Furthermore, whilst the current database utilised for our study provides insight into a diverse set of international media agendas, it should be noted that a bias towards OECD countries still exists due to the lack of electronically available broadsheet newspapers from developing and emerging economies. Alongside the on-going development of mainstream databases such as LexisNexis and Factiva, it should be possible to create a truly balanced international sample in the near future. Likewise, whilst robustness tests produced qualitatively 
equivalent results for all three years 2007-2009, future research should also examine the extent to which our results also hold true for years located outside of this time frame. The fact that consistent patterns could be identified throughout a three-year time period gives rise to the assumption that the observable patterns extend beyond this specific review period.

Whilst this paper has used a cross-sectional model, future research should add a longitudinal perspective and also build on the existing literature focusing on the link between the mass media and the general public in the context of climate change (Carvalho and Burgess, 2005; Trumbo, 1996), and thus validate and refine existing findings in light of different national and cultural contexts. Among others, this could include the role of tone and content of coverage on climate change (McComas and Shanahan, 1999) as well as the political alignment (Carvalho and Burgess, 2005) and communication strategies applied by broadsheet newspapers (Johnson, 2012; Smith, 2005). Likewise, the analysis should also be extended to other types of media and shed light on the potential impacts of different types of media systems on the nature and extent of coverage. Ultimately, a better understanding of how public and media agendas influence each other in different contexts will increase the prospects of substantive policy responses that address the risk of climate change more effectively.

\section{Declaration of conflicting interests}

The author(s) declared no potential conflicts of interest with respect to the research, authorship, and/or publication of this article.

\section{Funding}

The author(s) received no financial support for the research, authorship, and/or publication of this article.

\section{Notes}

1. Although the scope and content of these newspapers is likely to be affected by the choice of language, it was decided to include these publications into the sample for two reasons: (1) in the case of local deviations from the 'global mainstream', these English-language newspapers are still likely to reflect these national divergences at least to a certain extent; and (2) it could also be argued that in some of these countries such as Russia or China, the fact that these newspapers are published in English language allows these publications to remain more independent in terms of freedom of the press, therefore to a higher degree reflecting public opinion in these countries.

2. In this context, we are aware of the potential multicollinearity problem of GDP per capita and regulatory quality. The results from individual regression (4), (5) and (9) have been consistent, and hence we can confirm that these results are robust to a potential multicollinearity issue.

\section{References}

Aguilera RV and Jackson G (2003) The cross-national diversity of corporate governance: Dimensions and determinants. The Academy of Management Review 28: 447-465.

Anderson A (2009) Media, politics and climate change: Towards a new research agenda. Sociology Compass 3: 166-182.

Aykut SC, Comby J-B and Guillemot H (2012) Climate change controversies in French mass media 1990-2010. Journalism Studies 13: 157-174.

Barkemeyer R, Figge F, Hahn T, et al. (2009) What the papers say: Trends in sustainability. A comparative analysis of 115 leading national newspapers worldwide. Journal of Corporate Citizenship 33: 69-86. 
Bord RJ, O'Connor RE and Fisher A (2000) In what sense does the public need to understand global climate change? Public Understanding of Science 9: 205-218.

Boykoff MT (2007) Flogging a dead norm? Newspaper coverage of anthropogenic climate change in the United States and United Kingdom from 2003 to 2006. Area 39: 470-481.

Boykoff MT (2010) Indian media representations of climate change in a threatened journalistic ecosystem. Climatic Change 99: 17-25.

Boykoff MT and Boykoff JM (2007) Climate change and journalistic norms: A case study of US massmedia coverage. Geoforum 38: 1190-1204.

Boykoff MT and Mansfield M (2008) Ye olde hot aire: Reporting on human contributions to climate change in the UK Tabloid Press. Environmental Research Letters 3: 1-8.

Boykoff MT and Roberts JT (2007) Media coverage of climate change: Current trends, strengths, weaknesses. In: Human Development Report 2007/8 - United Nations Development Programme Occasional paper. [AQ4]New York, NY: Human Development Report Office.

Brossard D, Shanahan J and McComas K (2004) Are issue-cycles culturally constructed? A comparison of French and American coverage of global climate change. Mass Communication and Society 7: 359-377.

Brulle RJ, Carmichael J and Jenkins JC (2012) Shifting public opinion on climate change: An empirical assessment of factors influencing concern over climate change in the US, 2002-2010. Climatic Change 114: 169-188.

Burck J, Bals C, Beck M, et al. (2008) The Climate Change Performance Index 2008. Bonn: Germanwatch.

Carvalho A and Burgess J (2005) Cultural circuits of climate change in U.K. Broadsheet Newspapers, 1985-2003. Risk Analysis 25: 1457-1469.

CIA (2012) The World Factbook. Available at: https://www.cia.gov/library/publications/the-worldfactbook/geos/gm.html (accessed 22 January 2012).

Cohen BC (1963) The Press and Foreign Policy. Princeton, NJ: Princeton University Press.

Demeritt D (2001) The construction of global warming and the politics of science. Annals of the Association of American Geographers 91: 307-337.

Dietz T, Stern PC and Guagnano GA (1998) Social structural and social psychological bases of environmental concern. Environment and Behavior 30: 450-471.

Eckberg DL and Blocker TJ (1996) Christianity, environmentalism, and the theoretical problem of fundamentalism. Journal for the Scientific Study of Religion 35: 343-355.

EJC (2015) Media Landscapes. European Journalism Centre. Available at: http://ejc.net/media landscapes (accessed 7 August 2015) [AQ5].

Feldman R and Sanger J (2007) The Text Mining Handbook. Cambridge, MA: Cambridge University Press.

Ferner A and Quintanilla J (1998) Multinationals, national business systems and HRM: The enduring influence of national identity or a process of 'Anglo-Saxonization'. International Journal of Human Resource Management 9: 710-731.

Forsyth T (2007) Promoting the "development dividend" of climate technology transfer: Can crosssector partnerships help? World Development 35: 1684-1698.

Franzen A and Meyer R (2010) Environmental attitudes in cross-national perspective: A multilevel analysis of the ISSP 1993 and 2000. European Sociological Review 26: 219-234.

Galeotti M, Lanza A and Pauli F (2006) Reassessing the environmental Kuznets curve for $\mathrm{CO}_{2}$ emissions: A robustness exercise. Ecological Economics 57: 152-163.

Gordon JC, Deines T and Havice J (2010) Global warming coverage in the media: Trends in a Mexico City newspaper. Science Communication 32: 143-170.

Grossman GM and Krueger AB (1991) Environmental impacts of a North American free trade agreement. In: NBER Working Paper 3914. [AQ6]Cambridge, MA: National Bureau of Economic Research.

Grundmann R and Scott M (2014) Disputed climate science in the media: Do countries matter? Public Understanding of Science 23: 220-235.

Guiso L, Sapienza P and Zingales L (2006) Does culture affect economic outcomes? Journal of Economic Perspectives 20: 23-48. 
Guth JL, Green JC, Kellstedt LA, et al. (1995) Faith and the environment: Religious beliefs and attitudes on environmental policy. American Journal of Political Science 39: 364-382.

Harmeling S (2010) Global climate risk index 2010. Bonn: Germanwatch.

Hearst MA (1997) Text data mining: Issues, techniques, and the relationship to information access. In: UW/MS workshop on data mining, Seattle [AQ7].

Hearst MA (1999) Untangling text data mining. In: Thirty-seventh annual meeting of the Association for Computational Linguistics, pp.3-10 [AQ8].

Henderson-Sellers A (1998) Climate whispers: Media communication about climate change. Climatic Change 40: 421-456.

Hofstede G (1980) Culture's Consequences: International Differences in Work-Related Values. Beverly Hills, CA; London: Sage.

Hofstede G (2006) What did GLOBE really measure? Researchers' minds versus respondents' minds. Journal of International Business Studies 37: 882-896.

Holt D and Barkemeyer R (2012) Media coverage of sustainable development issues - Attention cycles or punctuated equilibrium? Sustainable Development 20: 1-17.

House RJ, Hanges PM, Javidan M, et al. (2004) Culture, Leadership and Organizations: The GLOBE Study of 62 Societies. Thousand Oaks, CA: Sage.

Howlett M (1997) Issue-attention and punctuated equilibria models reconsidered: An empirical examination of the dynamics of agenda-setting in Canada. Canadian Journal of Political Science 30: 3-30.

IEA (2016) Key World Energy Statistics. Vienna: International Energy Agency. Available at: http:// www.iea.org/statistics/ (accessed 14 May 2016).

Inglehart R and Baker WE (2000) Modernization, cultural change, and the persistence of traditional values. American Sociological Review 65: 19-51.

Ioannou I and Serafeim G (2012) What drives corporate social performance? The role of nation-level institutions. Journal of International Business Studies 43: 834-864.

Jackson G and Apostolakou A (2010) Corporate social responsibility in Western Europe: An institutional mirror or substitute? Journal of Business Ethics 94: 371-394.

Jepperson RL (1991) Institutions, institutional effects, and institutionalism. In: Powell WW and DiMaggio PJ (eds) The New Institutionalism in Organizational Analysis. Chicago, IL: University of Chicago Press, pp. 164-182.

Jogesh A (2012) A change in climate? Trends in climate change reportage in the Indian print media. In: Dubash NK (ed.) Handbook of Climate Change and India: Development, Politics and Governance. London: Earthscan, pp. 266-286.

Johnson BB (2012) Climate change communication: A provocative inquiry into motives, meanings, and means. Risk Analysis 32: 973-991.

Kahn ME and Kotchen MJ (2010) Environmental concern and the business cycle: The chilling effect of recession. NBER Working Paper No. 16241. [AQ9]Cambridge, MA: National Bureau of Economic Research.

Keeling CD, Whorf TP, Wahlen M, et al. (1995) Interannual extremes in the rate of rise of atmospheric carbon dioxide since 1980. Nature 375: 666-670.

Kingdon JW (1984) Agendas, Alternatives, and Public Policies. New York, NY: HarperCollins.

Kiousis S (2004) Explicating media salience: A factor analysis of New York times issue coverage during the 2000 U.S. Presidential Elections. Journal of Communication 54: 71-87.

Kleinschmit D and Sjöstedt V (2014) Between science and politics: Swedish newspaper reporting on forests in a changing climate. Environmental Science and Policy 35: 117-127.

Kolk A and Pinkse J (2011) The climate change - Development nexus and tripartite partnerships. In: Working Paper 006. Rotterdam: The Partnerships Resource Centre [AQ10].

Leiserowitz AA (2005) American risk perceptions: Is climate change dangerous? Risk Analysis 25: $1433-1442$.

Liu X, Lindquist E and Vedlitz A (2011) Explaining media and congressional attention to global climate change, 1969-2005: An empirical test of agenda-setting theory. Political Research Quarterly 64: 405-419. 
Longhofer W and Schofer E (2010) National and global origins of environmental association. American Sociological Review 75: 505-533.

Lorenzoni I, Nicholson-Cole S and Whitmarsh L (2007) Barriers perceived to engaging with climate change among the UK public and their policy implications. Global Environmental Change 17: 445-459.

Lundvall B-Å (1999) National business systems and national systems of innovation. International Studies of Management and Organization 29: 60-77.

McComas K and Shanahan J (1999) Telling stories about global climate change. Measuring the impact of narratives on issue cycles. Communication Research 26: 30-57.

McCombs ME (1977) Newspaper vs. television. In: Shaw DL and McCombs ME (eds) The Emergence of American Political Issues. St. Paul, MN: West, pp. 89-105.

McCombs ME (2004) Setting the Agenda. The Mass Media and Public Opinion. Cambridge: Polity Press.

Manning CD and Schütze H (2002) Foundations of Statistical Natural Language Processing. Cambridge, MA: MIT Press.

Maslow AH (1943) A theory of human motivation. Psychological Review 50: 370-396.

Matten D and Moon J (2008) "Implicit" and "explicit" CSR: A conceptual framework for a comparative understanding of corporate social responsibility. Academy of Management Review 33: 404-424.

Miah MD, Kabir MH, Koike M, et al. (2011) Major climate-change issues covered by the daily newspapers of Bangladesh. The Environmentalist 31: 67-73.

Michaelowa A and Michaelowa K (2007) Climate or development: Is ODA diverted from its original purpose? Climatic Change 84: 5-21.

Milfont TL (2012) The interplay between knowledge, perceived efficacy, and concern about global warming and climate change: A one-year longitudinal study. Risk Analysis 32: 1003-1020.

Moser SC (2010) Communicating climate change: History, challenges, process and future directions. Wiley Interdisciplinary Reviews: Climate Change 1: 31-53.

Nerlich B, Forsyth R and Clarke D (2012) Climate in the news: How differences in media discourse between the US and UK reflect national priorities. Environmental Communication: A Journal of Nature and Culture 6: 44-63.

Pasquaré FA and Oppizzi P (2012) How do the media affect public perception of climate change and geohazards? An Italian case study. Global and Planetary Change 90: 152-157.

Pidgeon N (2012) Climate change risk perception and communication: Addressing a critical moment? Risk Analysis 32: 951-956.

Poumadère M, Mays C, Le Mer S, et al. (2005) The 2003 heat wave in France: Dangerous climate change here and now. Risk Analysis 25: 1483-1494.

Powell WW and DiMaggio PJ (1991) The New Institutionalism in Organizational Analysis. Chicago, IL: University of Chicago Press.

Puglisi R and Snyder JM Jr (2011) Newspaper coverage of political scandals. Journal of Politics 73: 931-950.

Sabatier PA and Jenkins-Smith HC (1999) The advocacy coalition framework: An assessment. In: Sabatier PA (ed.) Theories of the Policy Process. Boulder, CO: Westview, pp. 117-166.

Schäfer MS, Ivanova A and Schmidt A (2014) What drives media attention for climate change? Explaining issue attention in Australian, German and Indian print media from 1996 to 2010. International Communication Gazette 76: 152-176.

Schäfer MS and Schlichting I (2014) Media representations of climate change: A meta-analysis of the research field. Environmental Communication 8: 142-160.

Schmidt A, Ivanova A and Schäfer MS (2013) Media attention for climate change around the world: A comparative analysis of newspaper coverage in 27 countries. Global Environmental Change 23: $1233-1248$.

Schultz PW, Zelezny L and Dalrymple NJ (2000) A multinational perspective on the relation between Judeo-Christian religious beliefs and attitudes of environmental concern. Environment and Behavior 32: $576-591$.

Smith J (2005) Dangerous news: Media decision making about climate change risk. Risk Analysis 25: 
$1471-1482$.

Sparks C (1987) The readership of the British quality press. Media, Culture and Society 9: 427-455.

Stedman RC (2004) Risk and climate change: Perceptions of key policy actors in Canada. Risk Analysis 24: 1395-1406.

Stern DI, Common MS and Barbier EB (1996) Economic growth and environmental degradation: The environmental Kuznets curve and sustainable development. World Development 24: 1151-1160.

Stern PC, Dietz T and Guagnano GA (1995) The new ecological paradigm in social-psychological context. Environment and Behavior 27: 723-743.

Takahashi B and Meisner M (2013) Climate change in Peruvian newspapers: The role of foreign voices in a context of vulnerability. Public Understanding of Science 22: 427-442.

Tan AH (1999) Text mining: The state of the art and the challenges. In: Pacific Asia Conference on Knowledge Discovery and Data Mining PAKDD'99 workshop on Knowledge Discovery from Advanced Databases, pp.65-70 [AQ11].

Taras V, Rowney J and Steel P (2009) Half a century of measuring culture: Review of approaches, challenges, and limitations based on the analysis of 121 instruments for quantifying culture. Journal of International Management 15: 357-373.

Tews K, Busch P-O and Jörgens H (2003) The diffusion of new environmental policy instruments. European Journal of Political Research 42: 569-600.

Tolbert PS and Zucker LG (1999) The institutionalization of institutional theory. In: Clegg SR, Clegg S and Hardy C (eds) Studying Organization. Theory \& Method. [AQ12]London: Thousand Oaks, pp. 169-184.

Trompenaars F and Hampden-Turner C (1997) Riding the Waves of Culture. Understanding Cultural Diversity in Global Business. New York, NY: McGraw-Hill.

Trumbo C (1996) Constructing climate change: Claims and frames in US news coverage of an environmental issue. Public Understanding of Science 5: 269-283.

UNDP (1995) Energy as an Instrument for Socio-economic Development. New York, NY: United Nations Development Programme.

UNDP (2007) Human Development Report 2007/2008. Fighting Climate Change: Human Solidarity in a Divided World. New York, NY: United Nations Development Programme.

Ungar S (2000) Knowledge, ignorance and the popular culture: Climate change versus the ozone hole. Public Understanding of Science 9: 297-312.

Weidner H and Jänicke M (2002) Capacity Building in National Environmental Policy. A Comparative Study of 17 Countries. Berlin, Heidelberg, New York, NY: Springer.

White L (1967) The historical roots of our environmental crisis. Science 155: 1203-1207.

Whitley R (1999) Divergent Capitalisms: The Social Structuring and Change of Business Systems. Oxford: Oxford University Press.

Witt MA and Redding G (2013) The Oxford Handbook of Asian Business Systems. Oxford: Oxford University Press.

World Bank (2014) Worldwide Governance Indicators. World Bank Group. Available at: http://info. worldbank.org/governance/wgi/index.aspx\#home (accessed 22 December 2014) [AQ13].

Yang G (2010) Brokering environment and health in China: Issue entrepreneurs of the public sphere. Journal of Contemporary China 19: 101-118.

\section{Ralf Barkemeyer [AQ1]}

\section{Frank Figge 1}

\section{Andreas Hoepner}

\section{Diane Holt}




\section{Johannes Kraak}

\section{Pei-Shan Yu}

\section{Appendix I}

Graphical representation of average number of climate change-related articles per newspaper issue and standard deviation of monthly coverage levels per country.

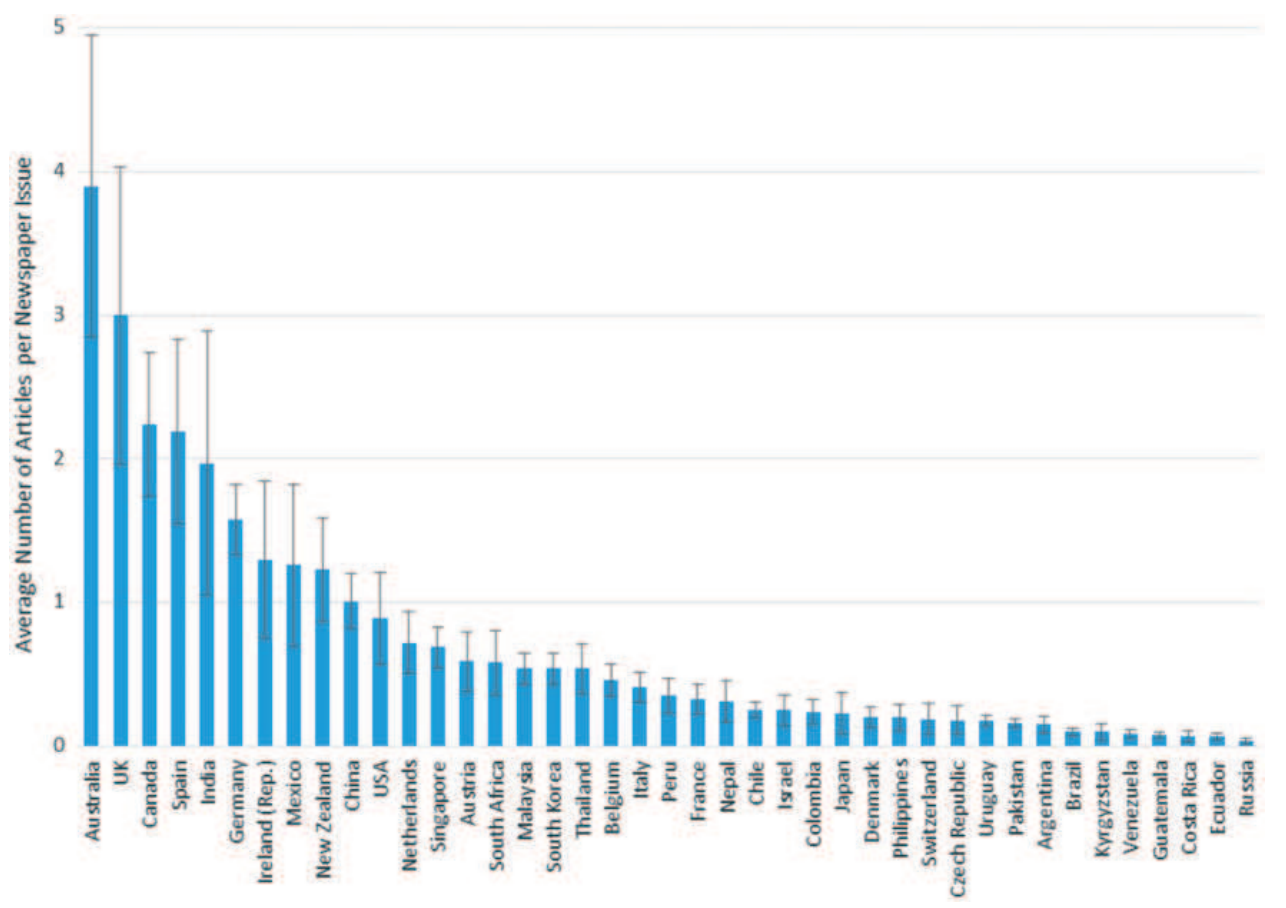

